\title{
抗癌剂門脈内反復投与による肝転移予防の実験的研究
}

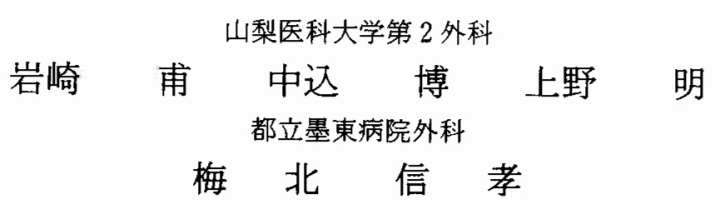

\section{AN EXPERIMENTAL STUDY OF REPETITIVE INTRAPORTAL INFUSION CHEMOTHERAPY AS A PROPHYLACTIC TREATMENT OF LIVER METASTASIS}

\author{
Masaru IWASAKI, Hiroshi NAKAGOMI and Akira UENO \\ Second Department of Surgery. Yamanashi Medical College
}

Nobutaka UMEKITA

Department of Surgery, Tokyo Metropolitan Bokutou Hospital

\begin{abstract}
抗癌剤の門脈内反復投与による肝転移予防効果についてVX2腫瘍とアドリアマイシンを用いて実 験的に検討した．家鬼の門脈にカテーテルを留置，VX2浮遊液 $\left(3 \sim 4 \times 10^{4}\right.$ 個 $\left./ \mathrm{ml}\right) 1 \mathrm{ml}$ を注入. 門 注群 $(\mathrm{N}=6)$ には当日から 1 週間 $0.8 \mathrm{mg} / \mathrm{kg}$ アドリアマイシンをカテーテルより投与, 対照群 $(\mathrm{N}=$ 6)には同期間生食水を投与した。 4 週間後, 門注群は全例生存し肝転移も 2 羽に散在性に認めたのみ であったが, 対照群では全例に多数の肝転移を認めた。平均肝重量は門注群 $107 \mathrm{~g}$, 対照群 $350 \mathrm{~g}$ であっ た。抗癌剤の門脈内反復投与法は明らかな肝転移抑制効果を示し, これを消化管癌術直後から開始す ることにより肝転移を予防できる可能性のあることが示唆された。
\end{abstract}

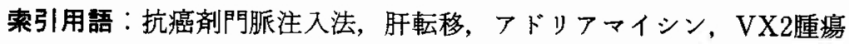

はじめに

消化管悪性腫㻛にお汁る肝転移は予後を決定する大 きな因子の一つであり，発生を予防もしくは抑制する ことができれば成績の向上がもたらされることが予想 される．この肝転移は門脈を経由して発生するとされ て拉り, 門脈内に腫埸細胞が流出する機会はその原発 巣手術時が最も多いと考只られる1)。したがって手術 直後から門脈内へ反復して抗癌剂を投与寸れば，これ らの逸脱した畽瘍細胞の肝組織内への着床を防止し て, 肝転移巣の形成を予防できる可能性がある。

この抗癌剤の門脈内反復投与は, 臨床的にはすでに Taylorらにより試みられて打り，投与群に肝転移の発 生が少ないことが報告されている2)3〉.しかし，これは 経過観察による結果の報告であり，この方法による肝 転移の予防・抑制効果についての基礎的検討は報告さ

$<1987$ 年12月 9 日受理 >別刷請求先：岩畸 甫 于409-38 山梨県中巨摩郡玉穗町下河東1110 山梨医 科大学第 2 外科
れていない。

今回，私どもは家象可移植性 VX2腫場を用い，また 抗癌剂として肝組織への集積性が高いとされるアドリ アマイシン(以下 ADR と略す)を選び，抗癌剤の門脈 内反復投与による悪性腫瘍の肝転移予防・抑制効果の 有無を実験的に検討したので報告する.

\section{方 法}

1. VX2浮遊細胞液の作成

$\mathrm{VX} 2$ 坦癌家鬼 (協和発酵研究所より提供を受けた) をネンブタール $25 \mathrm{mg} / \mathrm{kg}$ 静注にて全身麻酔を施し, 右 下肢に移植・生育したVX2腫瘍を切除, 壊死となって いる腫瘍中央部を唅て, 白色の硬い腫瘍辺縁部を選び, これを CMF-Hanks 液中にて眼科用剪刀を用いて，ほ ぼ5 6mm 大の腫場片を作成した。この腫場片をメス にて細切後メッシュにて濾過し CMF.Hanks 液を加 えて希积した. Neubauer 血球計算板にて腫湯細胞数 を計測し， $3 \sim 4 \times 10^{4}$ 個/ $\mathrm{ml}$ に調整，これを $\mathrm{VX} 2$ 細胞 浮遊夜として次の実験に用いた。 


\section{ADR 門脈内反復投与による肝転移抑制実験}

体重2.5 3.5kg の家鬼 (Japanese white) 12 羽を用 い,ネンブタール $25 \mathrm{mg} / \mathrm{kg}$ 静注にて全身麻酔し自発呼 吸下に開腹, 前腸間膜静脈の分枝である回盲腸静脈を 露出，この静脈よりへパリン・コーティング・カテー テルを門脈へ插入・固定した。カテーテルは鬼による 破損防止と以後の薬剂注入のため開腹創から皮下を経 由乙背部へ誘導・固定した。固定後このカテーテルを 通して, 先に準備した VX2浮遊細胞液 $1 \mathrm{ml}$ を門脈内一 注入した。この後, 家鬼を同数ずつ抗癌剂門脈内反復 投与群（以下門注群之略す） と，生理的食塩水投与群 （以下対照群と略す）に分けた。すなわち門注群とした 家鬼には VX2細胞注入 1 時間後に0.8mg/kg ADR を 門脈内留置カテーテルを通して注入し，その後へパリ ン加生食水 $1 \mathrm{ml}$ にて洗浄しカテーテルの閉塞を予防し た. 以後連日 6 日間，1日 1 回同量の ADR をカテーテ ルより注入した。これに対し対照群では生理的食塩水 を同期間同様に $2 \mathrm{ml}$ ずつ注入した。 VX2 細胞投与後は 両群とも通常の方法にて飼育して 4 週間まで観察し た. 4 週間後, 生存した家鬼む儀牲死させ, 両群の個々 の症例につき生存日数・肝転移状況・肝重量を比較検 討した。

\section{結 果}

門注群：6 羽全例が 4 週間生存した。肝転移状況は, 4 羽では肉眼的には肝転移巣を全く認めなかった。他 の 2 羽の肝表面には散在性に数個の白色結節が観測さ れ, 組織学的検索により VX2細胞を認め転移巣と診断 された。肝蔵の重量は肝転移の認められなかった家鬼 で80 $100 \mathrm{~g}$, 平均 $85 \mathrm{~g}$ で, 散在性に転移を認めた 2 羽で は100 200g, 平均 $150 \mathrm{~g}$ であり, 門注群全体の平均肝重

図 1 VX2投与 4 週間後の門注群(No. 3)の摘出肝標 本. 肝臓表面に転移巣の形成は認められず，ほ注正

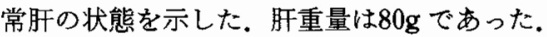

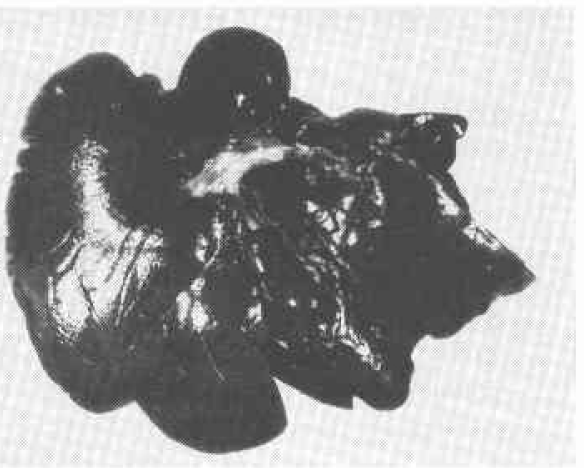

量は107gであった（図 1).

対照群：4 週間生存した家鬼は 2 羽のみで，他はそ れぞれ15日目，17日目，25日目，26日目に腫堭死した。 腫瘍死亡時㧍よび檥牲死時の肝嵗の検索では，すべて の症例で肝臓の著しい腫大と直径 $1 \sim 2 \mathrm{~cm}$ の多数の白 色結節を認め，VX2細胞による転移巣之診断された。 肝臟重量は270 420g，平均 $350 \mathrm{~g}$ であった（図 2 ）。

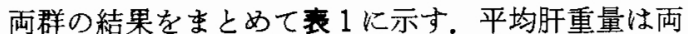
群間で有意な差を示した $(\mathrm{p}<0.01)$.

\section{考寀}

肝臓は悪性腫瘍における血行性転移の好発部位であ ク, 特に消化管悪性腫瑝では剖検時に約半数の症例に 肝転移が認められる4)，肝転移をきたした症例の予後 は現在でもきわめて不良であり, 北條は5占腸癌の肝 転移非切除例で 3 年生存例は 140 例中 4 例のみであり

图 2 VX2投与 4 週間後の対照群 (No. 11) の摘出標 本．肝臟全体に多数の転移栄が認められ，著しい腫 大を示した。肝重量は290gであった。

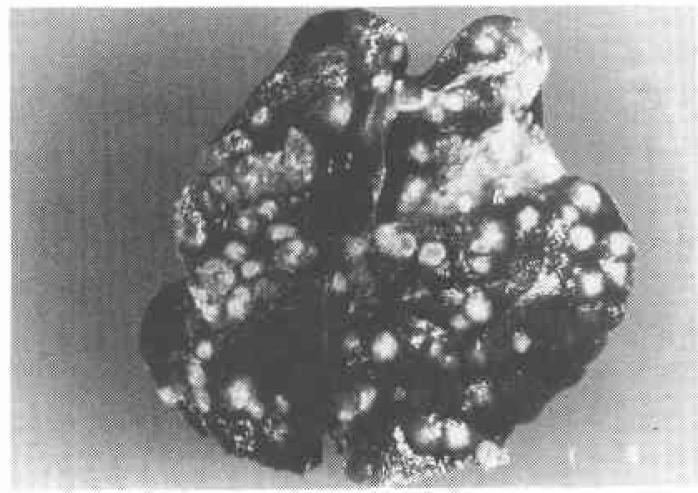

表 1 VX2投与後 4 週間までの門注群および対照群 での生存日数・肝転移状況・肝重量および両群の平 均肝重量 (S ; 生存, + ; 死亡). 門注群は全例生存し たが，対照群では生存例は 2 例のみであった。転移 晕の形成も両群間で著しい差を認め，平均肝重量は 有意な差を示した $(\mathrm{p}<0.01)$.

\begin{tabular}{|c|c|c|c|c|c|}
\hline & & $0-5-10-15-20-25-28$ & 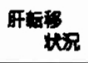 & 睡年 & $\begin{array}{l}\text { 平均 } \\
\text { 䀘至量 }\end{array}$ \\
\hline P泣资 & $\begin{array}{l}\text { No. } 1 \\
\text { No. } 2 \\
\text { No. } 3 \\
\text { No. } 4 \\
\text { No. } 5 \\
\text { No. } 6\end{array}$ & 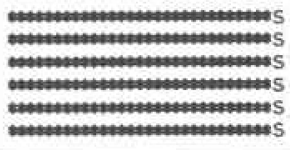 & 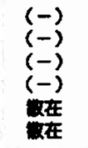 & $\begin{array}{r}80 \\
80 \\
80 \\
100 \\
100 \\
200\end{array}$ & 1078 \\
\hline 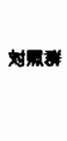 & $\begin{array}{l}\text { No. } 7 \\
\text { No. } 8 \\
\text { No. } 9 \\
\text { No. } 10 \\
\text { No. } 11 \\
\text { No. } 12\end{array}$ & 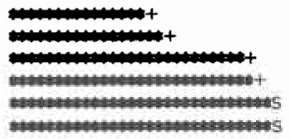 & & $\begin{array}{l}350 \\
420 \\
390 \\
380 \\
290 \\
270\end{array}$ & 3508 \\
\hline
\end{tabular}


5 年生存例はなかったと報告している.

消化管悪性腫瘍の肝転移は，そのほとんどが門脈経 由とされており6), 腫瘁細胞の門脈内への逸脱は腫瘍 の増大に伴う自然経過を別とすれば，手術操作時の場 合が最も大さいと考光られる7). Turnbull による isolation technique での成績の向上")は，逆に術中に細胞 の逸脱する機会の多いことを示しているといえる。こ れらの遊離した細胞は数日の経過の後に着床して微小 転移巣を形成する ことから, 腫湟細胞が個々の細胞 単位で存在している手術直後の段階で抗癌剤を作用さ せれば尰瘍細胞の着床を妨げて，肝転移の形成を未然 に防止できる可能性があり，この点に門注療法の意味 があるとい方る。

腫瘍細胞は小葉間静脈または洞様毛細血管で捕捉さ れると考えられる。洞様毛細血管には肝動脈からの血 流もあることから抗癌昘の動脈内注入（動注）でも門 脈内注入 (門注) と同様な效果があるものと思われる. しかし門注ではいずれかの門脈の末梢枝から抗癌剤を 投与すれば，そのすべては肝葴へ流入するのに対して， 動注では肝葴以外の臓器への抗癌剂の流入を防止する 必要があり，いまだ転移巣の形成されていない状態で の予防的投与には門脈からの注入法が合目的的々いえ る。ぬた，すでに形成された肝転移巣はそのほとんど が肝動脈支配となるため門脈からの薬昘投与では治療 が困難であるが，被膜や小転移巣は門脈支配の部分も あり ${ }^{10)}$, 門注療法は動注㞠法の補助療法としての意義 ああると思われる。

これまでにもこのような観点から門脈内への抗癌剤 投与は試みられていたが，多くの場合は術中の 1 回投 与であった ${ }^{11)}$. 梅北らによれば12)抗癌剤の門脈投与に よる有効血中濃度の持続時間は短く30分後にはほぼ投 与前のレベルにもどることが示され，1回のみの投与 では門脈中の腫瘍細胞の多くを死隇させることは困難

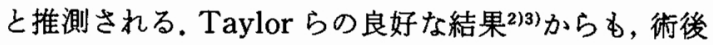
に門脈内へ散逸した癌細胞の肝組織への着床を防止す るためには一定期間の抗癌剂の持続的投与が必要なこ とと考えられる.

VX2腫瘍は Shope virus 由来の家鬼可移植性腫汮 ${ }^{13)}$ でその維持および細胞分離などが比較的容易なため実 験腫瘍として広く用いられている，今回の肝転移実験 モデルは分離した VX2細胞を門脈血中に直接注入す る方法を取った．対照群では全例に訮臓に白色の腫瘍 結節が形成され，この結節を転移巣と見なすことによ り肝転移のモデルとしてほぼ臨床の状態に即したるの
を提供していると考えた。 また動注療法では濃度依存 性抗癌風がより有効とされて和り ${ }^{14)}$, 門注でも同様と 考えられるため今回の実験には組織吸着性も強く, ま たVX2腫場に感受性を示す15)アドリアマイシンを抗 癌剤として選択した。

今回の実験結果から 1 週間の抗癌剤の門脈内への反 復投与はVX2腫崵の肝組織への着床を防止して訮転 移に対する明らかな抑制効果のあることが示された。 今後は薬物の至適投与期間や至適投与量なとの設定 や，インターロイキンなどの各種のサイトカインを加

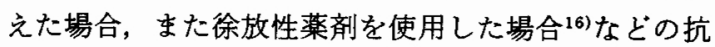
転移効果を検討する必要があ万う.今回の結果はVX2 腫瘍とい5比較的増殖速度の早い実験腫瘍を使用して の結果であるので，ここで得られた結果をそのまま臨 床の場に打いて期待することは難しいと思われる. 臨 㦿で遭遇する腫痬はおのおの異なった組織型や増殖速 度を示すため，この方法の臨床応用の際には投与薬剤 の選択，投与期間掞よび投与経路の設定など臨床の場 に即した形でこれらの点が解决されなければならな い.しかし抗癌剤の門脈内への反復投与法は消化管覀 珄尰瘍の肝転移の抑制に効果の高い方法であり，これ を臨床的に用いることにより消化管悪性腫瘍の成績の 向上がるたらされるものと期待される.

\section{結語}

家鬼可移植性 VX2腫瘍を用い，また抗癌剤としてア ドリアマイシンを選択して, 抗癌剤の門脈内反復投与 による肝転移抑制効果について検討した，門注群では 6 羽中 4 羽に全く転移を認めず，他の 2 羽に少数の転 移を見たのみであったが，対照群では全例に多数の肝 転移を認め，反復的門注による転移㧕制効果の高いこ とが示された。

この方法を消化管悪性厘瑒の手術直後から施行する ことにより臨床的にも肝転移を予防ないし抑制でさる 可能性のあることが示唆された。

本論文の要旨は第29回日本消化器外科学会総会に拈いて 発表した。

\section{文献}

1) Fisher B, Turnbull ER: The cytological demonstration and significance of tumor cells in the mesentric venous blood in patients with colorectal cancer. Surg Gynecol Obstet 100 : 102-107, 1955

2) Taylor I, Brooman P, Rowling JT : Adjuvant liver perfusion in colorectal cancer: Initial results of a clinical trial. Br Med J 19: 
1320-1322, 1977

3) Taylor I, Rowling J, West C: Adjuvant cytotoxic liver perfusion for colorectal cancer. Br J Surg 66:833-837, 1979

4）海藤 勇, 伊藤俊一：転移性肝癌. 吉利 和, 中尾 喜久, 山形敞一ほ編。新内科学大系 Vol 223 , 肝疾患 IV, 中山書店, 東京, 1986, p341-344

5）北條慶一：進行大腸癌の外科治療. 癌と化療 $13: 2282-2290,1986$

6) Engel HC: Cancer cells in the circulating blood. Acta Chir Scand [Suppl〕 $201: 1-69$, 1955

7) Fisher B, Fisher ER: Experimental studies of factors influencing hepatic metastasis. III. Effect of surgical trauma with special reference to liver injury. Ann Surg 150:731-743, 1959

8) Turnbull RB Jr: Cancer of the colon. The five-and ten-year survival rates following resec. tion utilizing the isolation technique. Ann $R$ Coll Surg 46:243-250, 1970

9）螺良英郎, 西川秀樹, 智片英治汪か：臨床の立場か ら転移の問題点を探る. 癌と化療 $12 ： 1189-$ 1195, 1985
10) Brecidis C, Young G: The blood supply of neoplasms in the liver. Am J Pathol 30 : 969-977, 1954

11) Morales F, Bell M, Mcdonald GO et al: The prophylactic treatment of cancer at the time of operation. Ann Surg 146:588-595, 1957

12）海北信孝, 岩崎 甫, 中込 博ほか: 門脈内注入时 のAdriamycinの薬物動態. 山梨医大誌 2: 69-72, 1987

13) Rous P, Kidd JG, Smith WE: The progression to carcinoma of virus-induced rabbit papillomas(Shope). J Exp Med $62: 523-548$, 1935

14）田口鐵男：動脈内投与法の理論とその臨床応用. 癌と化療 $12: 839-843,1985$

15) Swistel AJ, Bading JR, Raaf JH : Intraaretial versus intravenous adriamycin in the rabbit VX2 tumor system. Cancer 53: 1397-1404, 1984

16）山崎謙治, 今野俊光, 宮内好正ほか：油性制癌剂門 脈内投与による肝転移予防の実験的研究. 癌と化 療 $14 ： 1224-1228,1987$ 